\title{
Synthesis and Characterization of Ruthenium Amidinate Complexes as Precursors for Vapor Deposition
}

\author{
Huazhi $\mathrm{Li}^{1}$, Titta Aaltonen ${ }^{2}$, Zhengwen $\mathrm{Li}^{3}$, Booyong S. Lim and Roy G. Gordon* \\ Department of Chemistry and Chemical Biology, Harvard University, Cambridge, Massachusetts 02138, USA \\ Current addresses: \\ ${ }^{I}$ Rohm and Haas Electronic Materials, 60 Willow Street, North Andover, MA 01845, USA \\ ${ }^{2}$ Centre for Materials Science and Nanotechnology, University of Oslo, PO Box 1033, Oslo N-0315, Norway \\ ${ }^{3} I B M$, Semiconductor R\&D Center, Fishkill, New York, USA \\ ${ }^{4}$ Hamilton, Brook, Smith \& Reynolds, 530 Virginia Rd., Concord, MA 01742-9133, USA
}

\begin{abstract}
Three new ruthenium amidinate complexes were prepared: tris(diisopropylacetamidinato)-ruthenium(III), $\mathrm{Ru}\left({ }^{i} \operatorname{PrNC}(\mathrm{Me}) \mathrm{N}^{i} \mathrm{Pr}\right)_{3}$ 4; bis(diisopropyl-acetamidinato)ruthenium(II) dicarbonyl, $\mathrm{Ru}\left({ }^{i} \operatorname{PrNC}(\mathrm{Me}) \mathrm{N}^{i} \mathrm{Pr}\right)_{2}(\mathrm{CO})_{2}$ 5; and bis(ditert-butylacetamidinato)ruthenium(II) dicarbonyl, $\mathrm{Ru}\left({ }^{t} \mathrm{BuNC}(\mathrm{Me}) \mathrm{N}^{t} \mathrm{Bu}\right)_{2}(\mathrm{CO})_{2} 6$. They have been synthesized and characterized by ${ }^{1} \mathrm{H}$ NMR, TG and X-ray structure analysis. These three complexes were found to be monomeric and air stable. Compound 6 was found to have sufficient volatility and thermal stability for use in chemical vapor deposition (CVD) and atomic layer deposition (ALD) of ruthenium metal films.
\end{abstract}

Keywords: Ruthenium, amidinate, ALD, CVD.

\section{INTRODUCTION}

Chemical vapor deposition (CVD) is a process for forming thin films from vapors of one or more precursors. Atomic layer deposition (ALD) is a technique related to CVD in which a heated substrate is exposed alternately to two complementary precursors. The two ALD precursors undergo self-limiting chemisorption reactions, providing highly uniform and conformal film growth. Highly uniform and conformal thin films are needed in microelectronics with feature size shrinking to sub $90 \mathrm{~nm}[1,2]$ and magnetic information storage [3]. Recently a lot of interest was focused on the applications of ALD techniques. Displays have been made using ALD [4]. Magnetic disk drives now incorporate an ALD layer [5], and ALD insulating layers are used in microelectronic memory chips [6]. Ruthenium thin films are potentially important materials in microelectronics. Ruthenium has been demonstrated as a seedless diffusion barrier or adhesive diffusion barrier in copper interconnects under $90 \mathrm{~nm}$ [7]. Ruthenium was also found to be a potential material for capacitor electrodes in memory applications [8] and metal gate electrodes [6,9] because of its low resistivity and high thermal stability. Furthermore, it has a conductive oxide $\left(\mathrm{RuO}_{2}\right)$ which prevents further oxygen diffusion. In order to apply CVD and ALD techniques for processing ruthenium films effectively to the smaller and more complicated geometries used in microelectronics, new volatile, reactive and thermally stable chemical precursors for ruthenium are needed.

Several ruthenium precursors have been studied for CVD or ALD of ruthenium films. They are basically divided into

*Address correspondence to these authors at the Department of Chemistry and Chemical Biology, Harvard University, Cambridge, Massachusetts 02138, USA; E-mail: Gordon@ @ chemistry.harvard.edu two categories: ruthenium organometallic compounds containing $\mathrm{Ru}-\mathrm{C}$ bonds such as $\mathrm{Ru}_{3}(\mathrm{CO})_{12}$ [10] and ruthenocenes [11,12] such as $\mathrm{Ru}(\mathrm{Cp})_{2}$ and $\mathrm{Ru}(\mathrm{EtCp})_{2}$ [13] $(\mathrm{Cp}=$ cyclopentadienyl); and ruthenium $\beta$-diketonates [14] or $\mathrm{Ru}(\mathrm{CO})_{2}(\beta \text {-diketonates })_{2}[15]$. These precursors lack sufficient reactivity with common second reactants such as hydrogen, water, and ammonia. Thus the processes based on these precursors require energy-intensive plasmas or highly oxidizing reagents such as oxygen or ozone, which are not compatible with electrically conductive substrates such as titanium nitride, tantalum nitride or tungsten nitride.

Some volatile and thermally stable metal amidinates $[16,17]$ have been found to be effective for ALD and CVD of metals ( $\mathrm{Fe}, \mathrm{Co}, \mathrm{Ni}, \mathrm{Cu}, \mathrm{Ag}, \mathrm{Ru})$ [18], transition metal oxides $\left(\mathrm{MnO}, \mathrm{FeO}, \mathrm{CoO}, \mathrm{NiO}, \mathrm{Cu}_{2} \mathrm{O}\right)$ [19], lanthanide oxides $\left(\mathrm{La}_{2} \mathrm{O}_{3}, \mathrm{LaAlO}_{3}\right.$ [20], $\mathrm{PrAlO}_{3}$ [21], $\mathrm{Sc}_{2} \mathrm{O}_{3}$ [22], $\mathrm{Y}_{2} \mathrm{O}_{3}$ [23], $\mathrm{GdScO}_{3}$ [24], $\mathrm{Lu}_{2} \mathrm{O}_{3}$ [25]), nitrides $\left(\mathrm{Fe}_{x} \mathrm{~N}\right.$ [26], $\mathrm{Co}_{\mathrm{x}} \mathrm{N}$ [27], $\mathrm{Ni}_{\mathrm{x}} \mathrm{N}$ [28], $\mathrm{Cu}_{3} \mathrm{~N}$ [29]). These metal amidinate precursors provide several benefits compared with other types of ALD precursors. They have metal-nitrogen bonds that are reactive to molecular hydrogen (forming metals), water (forming oxides) and ammonia (forming nitrides). Also, incorporation of carbon and oxygen impurities into the films was found to be minimal. The by-products from these metal amidinate complexes are not corrosive to the deposited films, unlike the corrosive hydrogen halides released by the use of metal halide precursors. In general, the advantages of the metal amidinate precursors include sufficient volatility, low deposition temperature, high thermal stability and good quality of the films.

To date, a few well-defined amidinate complexes of ruthenium have been prepared. Homoleptic Ru(III) amidinate complexes that have been structurally characterized include $\mathrm{Ru}(\mathrm{Ph}-\mathrm{Me}-\mathrm{amd})_{3}$ [30] and $\mathrm{Ru}(\mathrm{Tol}-\mathrm{Me}-\mathrm{amd})_{3}$, with $\mathrm{Ph}=$ 
$\mathrm{C}_{6} \mathrm{H}_{5}$ and Tol $=\mathrm{C}_{6} \mathrm{H}_{4}\left(\mathrm{CH}_{3}\right)$ [31]. Heteroleptic $\mathrm{Ru}(\mathrm{II})$ amidinate complexes $\mathrm{Ru}(\mathrm{Ph}-\mathrm{Me}-\mathrm{amd})_{2}(\mathrm{COD})$ and $\mathrm{Ru}\left({ }^{i} \mathrm{Pr}-\mathrm{Me}-\right.$ amd $)_{2}(\mathrm{COD})(\mathrm{COD}=$ cyclooctadiene $)[32,33]$ have also been prepared and their structures been determined. However, no data concerning the volatility, reactivity or thermal stability of these complexes have been reported.

We found a way to make some new ruthenium amidinate complexes and explored their physical properties, especially properties with respect to their use as precursors for vapor deposition. Herein the synthesis and physical characterization of three new $\mathrm{Ru}(\mathrm{III})$ and $\mathrm{Ru}(\mathrm{II})$ amidinate complexes are described.

\section{RESULTS AND DISCUSSION}

Starting Materials mer- $\mathrm{RuCl}_{3}\left(\mathrm{Me}_{2} \mathrm{~S}\right)_{3} \mathbf{1},\left[\mathrm{RuCl}_{2}(\mathrm{CO})_{3}\right]_{2} 2$ and $\mathrm{RuCl}_{2}(\mathrm{CO})_{3}\left(\mathrm{C}_{4} \mathrm{H}_{8} \mathrm{O}\right) 3$

When we tried to prepare ruthenium amidinate complexes using the metathesis reaction of anhydrous ruthenium chloride $\left(\mathrm{RuCl}_{3}\right)$ with a lithium amidinate in ether or ether/THF mixtures, we found that this synthetic method was not efficient in synthesizing ruthenium amidinates. When anhydrous $\mathrm{RuCl}_{3}$ was used as a starting material, the yield of produced ruthenium amidinate complexes was extremely low. This low yield is probably due to relatively low solubility of anhydrous $\mathrm{RuCl}_{3}$ in ether or THF.

Starting materials, mer- $\mathrm{RuCl}_{3}\left(\mathrm{Me}_{2} \mathrm{~S}\right)_{3},\left[\mathrm{RuCl}_{2}(\mathrm{CO})_{3}\right]_{2}$ and $\mathrm{RuCl}_{2}(\mathrm{CO})_{3}\left(\mathrm{C}_{4} \mathrm{H}_{8} \mathrm{O}\right)$, which had relatively high solubility in ether or THF, were suitable for the synthesis of ruthenium amidinate compounds with relatively good yields. In particular, $\mathrm{RuCl}_{2}(\mathrm{CO})_{3}\left(\mathrm{C}_{4} \mathrm{H}_{8} \mathrm{O}\right)$ was a good starting material for synthesizing $\mathrm{Ru}\left({ }^{t} \mathrm{Bu}-\mathrm{Me}-\mathrm{amd}\right)_{2}(\mathrm{CO})_{2}$, (where ${ }^{t} \mathrm{Bu}-\mathrm{Me}$-amd $=$ $\left.\left[{ }^{t} \mathrm{BuNC}(\mathrm{Me}) \mathrm{N}^{t} \mathrm{Bu}\right]\right)$. $\left[\mathrm{RuCl}_{2}(\mathrm{CO})_{3}\right]_{2}$ was synthesized according to the literature [34] and dried under vacuum overnight before using it as a starting material for $\mathrm{Ru}\left({ }^{i} \mathrm{Pr}-\mathrm{Me}\right.$ amd $)_{2}(\mathrm{CO})_{2}$. Further recrystallization of $\left[\mathrm{RuCl}_{2}(\mathrm{CO})_{3}\right]_{2}$ from THF resulted in a good yield of $\mathrm{RuCl}_{2}(\mathrm{CO})_{3}\left(\mathrm{C}_{4} \mathrm{H}_{8} \mathrm{O}\right)$. For mer- $\mathrm{RuCl}_{3}\left(\mathrm{Me}_{2} \mathrm{~S}\right)_{3}$, several synthetic routes have been described [35-39]. The method described in [38] seems like a convenient way to make mer- $\mathrm{RuCl}_{3}\left(\mathrm{Me}_{2} \mathrm{~S}\right)_{3}$ without the complications of using toxic dimethylsulfide or reducing $\mathrm{Ru}(\mathrm{III})$ to $\mathrm{Ru}(\mathrm{II})$ by alcohol. We tried to scale up the preparation of mer- $\mathrm{RuCl}_{3}\left(\mathrm{Me}_{2} \mathrm{~S}\right)_{3}$ according to the literature method [38] and this resulted in a $30 \%$ yield. Then we improved the yield by adding twice as much dimethyl sulfoxide (DMSO) and concentrated hydrochloric acid as used previously [38]. Up to 8 grams of $m e r-\mathrm{RuCl}_{3}\left(\mathrm{Me}_{2} \mathrm{~S}\right)_{3}$ with a yield as high as $75 \%$ could be made in one batch. This new synthetic procedure may confirm the mechanism proposed by B. R. James and coworkers [35,37,39]: in strongly acidic conditions, DMSO reduces $\mathrm{Ru}(\mathrm{III})$ to $\mathrm{Ru}(\mathrm{II})$ while being oxidized to the sulfone as shown in reaction (1) of Scheme 1:

(1) $2 \mathrm{Ru}^{3+}+\mathrm{Me}_{2} \mathrm{SO}+\mathrm{H}_{2} \mathrm{O} \rightarrow 2 \mathrm{Ru}^{2+}+\mathrm{Me}_{2} \mathrm{SO}_{2}+2 H^{+}$

(2) $2 \mathrm{Ru}^{3+}+\mathrm{Me}_{2} \mathrm{~S}+\mathrm{H}_{2} \mathrm{O} \Leftrightarrow 2 \mathrm{Ru}^{2+}+\mathrm{Me}_{2} \mathrm{SO}+2 \mathrm{H}^{+}$

Scheme 1. Proposed mechanism to prepare mer $-\mathrm{RuCl}_{3}\left(\mathrm{Me}_{2} \mathrm{~S}\right)_{3} \mathbf{1}$.

DMSO also behaves as an oxidant, transforming Ru(II) back to $\mathrm{Ru}(\mathrm{III})$ at high temperature while itself being reduced to dimethylsulfide, which readily coordinates $\mathrm{Ru}(\mathrm{III})$. The second reaction is in equilibrium. With the introduction of supplemental DMSO, the equilibrium was pushed to the left side of reaction (2) and the yield of mer- $\mathrm{RuCl}_{3}\left(\mathrm{Me}_{2} \mathrm{~S}\right)_{3}$ was increased to $75 \%$, which is close to the yield reported for a small batch (ca. $0.2 \mathrm{~g}$ ). The ${ }^{1} \mathrm{H}$ NMR spectrum of the product mer- $\mathrm{RuCl}_{3}\left(\mathrm{Me}_{2} \mathrm{~S}\right)_{3}$ shows two paramagnetic signals at -10.5 and $-21.0 \mathrm{ppm}$. Their intensities have a ratio of $1: 2$, indicative of a mer structure. All three starting materials have much better solubility in $\mathrm{Et}_{2} \mathrm{O}$ or THF than the anhydrous $\mathrm{RuCl}_{3}$.

The ruthenium compounds were prepared according to Scheme 2:

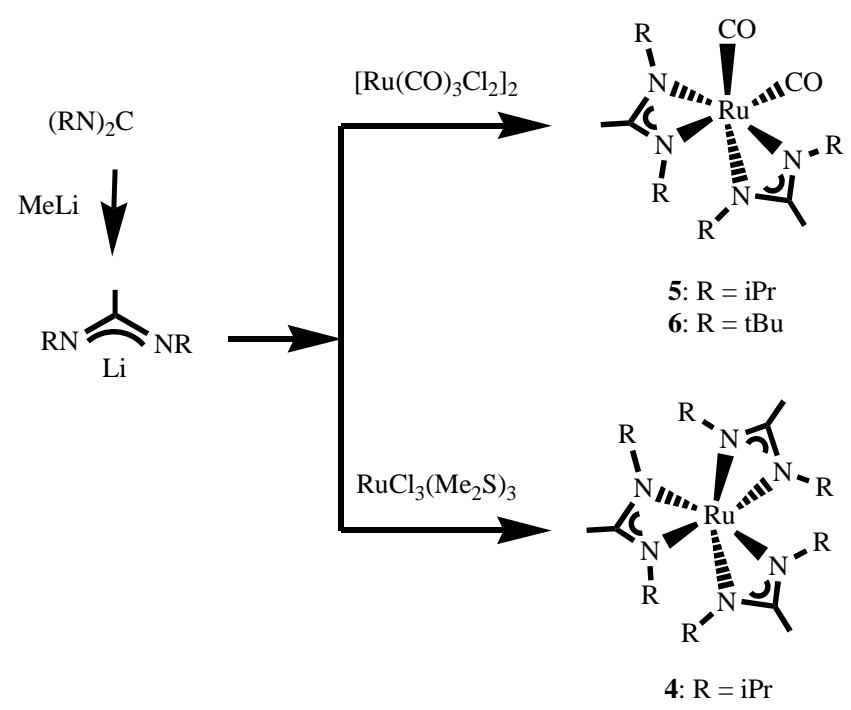

Scheme 2. Synthesis of Ru amidinate complexes 4, 5 and 6.

\section{$\operatorname{Ru}(i \operatorname{Pr}-M e A M D)_{3} 4$}

When mer- $\mathrm{RuCl}_{3}\left(\mathrm{Me}_{2} \mathrm{~S}\right)_{3}$ was reacted with (1,3-di-isopropylacetamidinato)-lithium, $\mathrm{Li}\left({ }^{i} \mathrm{Pr}-\mathrm{Me}\right.$-amd) (where ${ }^{i} \mathrm{Pr}$ Me-amd $\left.={ }^{i} \operatorname{PrNC}(\mathrm{Me}) \mathrm{N}^{i} \mathrm{Pr}\right)$, a blue material was isolated. An $\mathrm{X}$-ray crystal structure analysis of the blue material showed it to be the monomeric compound $\mathrm{Ru}\left({ }^{i} \mathrm{Pr}-\mathrm{Me}-\mathrm{amd}\right)_{3}$ and the structure is shown in Fig. (1).

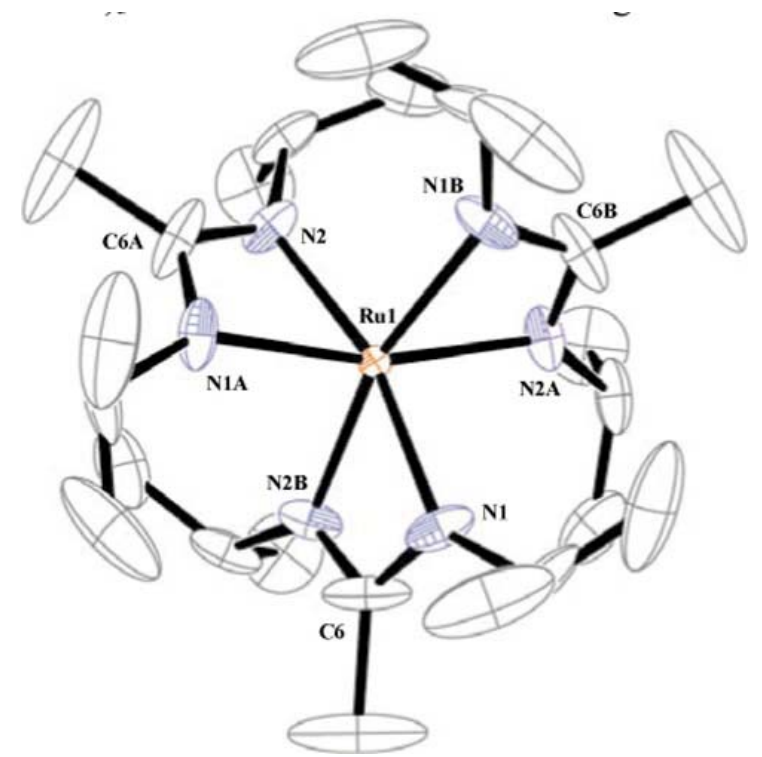

Fig. (1). Molecular structure of compound 4 with $50 \%$ thermal ellipsoids; hydrogen atoms are omitted for clarity. 
The ${ }^{1} \mathrm{H}$ NMR spectra of $\mathrm{Ru}\left({ }^{i} \mathrm{Pr}-\mathrm{Me}-\mathrm{amd}\right)_{3}$ in mesitylene$d_{12}$ showed no evidence for dimeric or oligomeric structures between $0{ }^{\circ} \mathrm{C}$ and $175^{\circ} \mathrm{C}$. Due to the $\mathrm{d}^{5}$ electronic structure, its ${ }^{1} \mathrm{H}$ NMR spectra at room temperature showed broad, but well resolved paramagnetic resonances. Integration helped to attribute four observed resonances (at $\delta=27.931,4.595$, $5.548,-18.499)$ to the $\mathrm{CH}\left(\mathrm{CH}_{3}\right)_{2}$, endo- $\mathrm{CH}\left(\mathrm{CH}_{3}\right)\left(\mathrm{CH}_{3}\right)$, exo$\mathrm{CH}\left(\mathrm{CH}_{3}\right)\left(\mathrm{CH}_{3}\right), \mathrm{CCH}_{3}$ groups, respectively. The two methyl groups in the same ${ }^{i} \operatorname{Pr}$ moiety differentiated by around 10 ppm because of their distance with the paramagnetic center $\mathrm{Ru}(\mathrm{III})$. This compound is air stable, which makes it easy to handle when used as a precursor. Electron impact mass spectrum (EI mass) gave a parent peak $\left(\left[\mathrm{M}^{+}\right]=524.8\right)$ matching the calculated molecular weight of 524.8 for $\mathrm{Ru}\left({ }^{i} \mathrm{Pr}-\mathrm{Me}-\right.$ amd $)_{3}$, and an accurate isotope pattern. Reaction of mer$\mathrm{RuCl}_{3}\left(\mathrm{Me}_{2} \mathrm{~S}\right)_{3}$ with other lithium amidinate salts such as (1,3-di- $n$-propyl-acetamidinato) lithium, (1,3-di-sec-butylacet-amidinato)lithium, (1,3-di-tert-butyl-acet-amidinato)lithium were also tried. The crude products were not thermally stable during sublimation, so they could not be prepared in pure form.

In the synthesis of $\mathrm{Ru}\left({ }^{i} \mathrm{Pr}-\mathrm{Me}-\mathrm{amd}\right)_{3}$, a significant amount of an organic impurity was isolated. It can be distilled as a colorless liquid at $50{ }^{\circ} \mathrm{C}$ under the pressure of 70 mTorr. Based on its NMR spectra and high resolution mass spectrum (HRMS), we think this unknown compound is the hydrazine 7 shown in Fig. (2).<smiles>CC(C)=NC(C)=NC(C)=NC(C)C</smiles>

Fig. (2). Schematic structure of compound 7 with NMR assignments.

Because of the steric hindrance between the ${ }^{i} \operatorname{Pr}$ groups and the nitrogen lone pair of electrons, the free rotation of the N-N single bond and all the N-C single bonds were restricted at room temperature, causing the two methyl groups in the same ${ }^{i} \mathrm{Pr}$ fragment to differentiate at room temperature. Its ${ }^{1} \mathrm{H}$ NMR spectra shows two septets (4.436 and 3.435, two different methylene protons e and f), one singlet (1.158, backbone methyl groups, g) and four sets of methyl groups $(1.238,1.197,1.195$ and 1.157). At a higher temperature (ca. $70{ }^{\circ} \mathrm{C}$ ) the four sets of methyl groups in the $i \operatorname{Pr}$ fragments merged into two doublets, while the other peaks stay the same. That means at higher temperature the $\mathrm{N}-\mathrm{N}$ single bond and all the $\mathrm{N}-\mathrm{C}$ single bonds can freely rotate. The ${ }^{13} \mathrm{C}$ NMR spectra at room temperature also shows four very close chemical shifts with resonances at 25.2, 25.0, 20.9 and 20.6, which correspond to 4 different methyl groups in the $i \mathrm{Pr}$ fragments. Subsequent elemental analysis matched the assigned structure. A HR MS shows that it has a parent peak at 283.2857, which is within $1.5 \mathrm{ppm}$ experimental error of the calculated molecular weight (283.2861). The isolation of this new hydrazine may suggest that two amidinate ligands were oxidized by $\mathrm{Ru}(\mathrm{III})$ center to join at the $\mathrm{N}$ sites to form the new hydrazine compound. In the literature $\mathrm{Ru}(\mathrm{III})$ has been found to perform the same function in heteroannulation processes and $\mathrm{N}$-alkylation of amides [36,38]. This reductive elimination pathway found in the synthesis of $\mathrm{Ru}(\mathrm{III})$ amidinate complexes suggests a new way to make novel hydrazine compounds and also a new decomposition pathway for metal amidinate precursors.

\section{$\mathrm{Ru}(i \mathrm{Pr}-\mathrm{Me}-\mathrm{amd})_{2}(\mathrm{CO})_{2} 5$ and $\mathrm{Ru}(t \mathrm{Bu}-\mathrm{Me}-\mathrm{amd})_{2}(\mathrm{CO})_{2} 6$}

$\left[\mathrm{RuCl}_{2}(\mathrm{CO})_{3}\right]_{2}$ was reacted with lithium $N, N^{\prime}$-di-isopropylacetamidinate to give $\mathrm{Ru}\left({ }^{i} \mathrm{Pr}-\mathrm{Me}-\mathrm{amd}\right)_{2}(\mathrm{CO})_{2}$, a yellow waxy dimagnetic material. The compound is very soluble in hexanes. The IR spectra of this compound shows two carbonyl vibrations with equal intensity $(v(\mathrm{CO})=2015$, $1936 \mathrm{~cm}^{-1}$ ), indicating a cis-dicarbonyl structure. The ${ }^{1} \mathrm{H}$ NMR and ${ }^{13} \mathrm{C}$ NMR spectra of this compound shows one backbone methyl group and two nonequivalent ${ }^{i} \mathrm{Pr}$ groups, each with two diastereotopic methyl groups. They were well resolved, which means $\mathrm{Ru}\left({ }^{i} \mathrm{Pr}-\mathrm{Me}-\mathrm{amd}\right)_{2}(\mathrm{CO})_{2}$ is nonfluxional on the NMR time scale at ambient temperature. Taking the NMR and the IR data into consideration, a $C_{2}$-symmetric octahedral cis-bis $\left(\eta^{2}\right.$-amidinate) $\mathrm{Ru}(\mathrm{CO})_{2}$ structure is suggested. This is also confirmed by single crystal X-ray structure of $\mathrm{Ru}\left({ }^{t} \mathrm{Bu}-\mathrm{Me}-\mathrm{amd}\right)_{2}(\mathrm{CO})_{2}$, which is shown in Fig. (3). $\mathrm{Ru}\left({ }^{t} \mathrm{Bu}-\mathrm{Me} \text {-amd }\right)_{2}(\mathrm{CO})_{2}$ was prepared in good yield when $\mathrm{RuCl}_{2}(\mathrm{CO})_{3}\left(\mathrm{C}_{4} \mathrm{H}_{8} \mathrm{O}\right)$ was reacted with lithium $N, N^{\prime}$-di-tertbutylacetamidinate. The compound yielded pale yellow crystals by sublimation. Its IR spectrum is very similar to that of $\mathrm{Ru}\left({ }^{i} \mathrm{Pr}-\mathrm{Me}-\mathrm{amd}\right)_{2}(\mathrm{CO})_{2}$. The carbonyl vibration for both compounds are found at similar wavelengths to those of the analogue $\mathrm{Fe}\left({ }^{i} \mathrm{Pr}-{ }^{t} \mathrm{Bu}-\mathrm{amd}\right)_{2}(\mathrm{CO})_{2}\left(2009,1942 \mathrm{~cm}^{-1}\right)$ [40]. Both $\mathrm{Ru}\left({ }^{i} \mathrm{Pr}-\mathrm{Me}-\mathrm{amd}\right)_{2}(\mathrm{CO})_{2}$ and $\mathrm{Ru}\left({ }^{t} \mathrm{Bu}-\mathrm{Me}-\mathrm{amd}\right)_{2}(\mathrm{CO})_{2}$ are air-stable. The solutions of both compounds in benzene did not undergo any change when exposed to air. When irradiated by a UV lamp under $\mathrm{N}_{2}$, the solutions of both compounds were observed stable to be at least 12 hours.

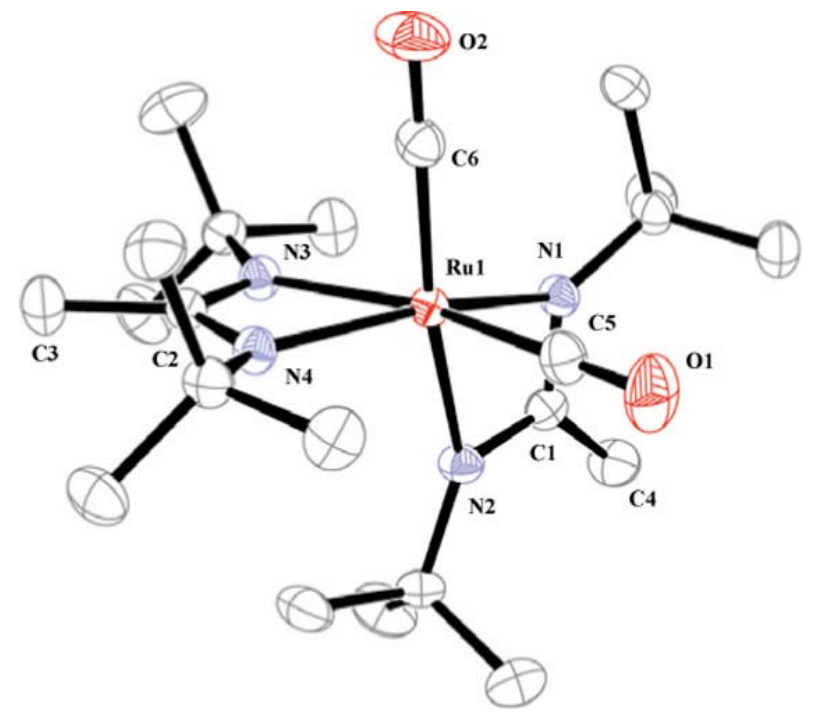

Fig. (3). Molecular structure of compound 6 with $50 \%$ thermal ellipsoids; hydrogen atoms are omitted for clarity.

\section{X-Ray Analysis}

Fig. (1) shows the molecular structure of $\mathrm{Ru}\left({ }^{i} \mathrm{Pr}-\mathrm{Me}-\right.$ amd) $)_{3}$ with $50 \%$ thermal ellipsoids and selected bond distance and angles are listed in Table $\mathbf{1 .}$ 
Table 1. Selected Interatomic Distances $(\AA)$ and Bond Angles $\left(^{\circ}\right)$ in Complex 4

\begin{tabular}{|c|c|}
\hline $\mathrm{Ru}(1)-\mathrm{N}(1)$ & $2.074(11)$ \\
\hline $\operatorname{Ru}(1)-N(1 \mathrm{~A})$ & $2.074(12)$ \\
\hline $\mathrm{Ru}(1)-\mathrm{N}(1 \mathrm{~B})$ & $2.074(11)$ \\
\hline $\mathrm{Ru}(1)-\mathrm{N}(2)$ & $2.090(12)$ \\
\hline $\operatorname{Ru}(1)-N(2 A)$ & $2.074(12)$ \\
\hline $\mathrm{Ru}(1)-\mathrm{N}(2 \mathrm{~B})$ & $2.074(12)$ \\
\hline$N(1)-C(6)$ & $1.354(16)$ \\
\hline $\mathrm{N}(2 \mathrm{~B})-\mathrm{C}(6)$ & $1.289(15)$ \\
\hline$N(2)-C(6 A)$ & $1.289(15)$ \\
\hline$N(1 A)-C(6 A)$ & $1.354(16)$ \\
\hline$N(1 B)-C(6 B)$ & $1.354(16)$ \\
\hline$N(2 A)-C(6 B)$ & $1.289(15)$ \\
\hline $\mathrm{N}(1)-\mathrm{Ru}(1)-\mathrm{N}(2 \mathrm{~B})$ & $62.8(3)$ \\
\hline $\mathrm{N}(1 \mathrm{~A})-\mathrm{Ru}(1)-\mathrm{N}(2)$ & $62.8(3)$ \\
\hline $\mathrm{N}(1 \mathrm{~B})-\mathrm{Ru}(1)-\mathrm{N}(2 \mathrm{~A})$ & $62.8(3)$ \\
\hline $\mathrm{N}(1)-\mathrm{Ru}(1)-\mathrm{N}(1 \mathrm{~B})$ & $105.4(4)$ \\
\hline $\mathrm{N}(2)-\mathrm{Ru}(1)-\mathrm{N}(2 \mathrm{~A})$ & $105.2(4)$ \\
\hline $\mathrm{N}(2)-\mathrm{Ru}(1)-\mathrm{N}(1 \mathrm{~B})$ & $88.0(4)$ \\
\hline $\mathrm{N}(1)-\mathrm{Ru}(1)-\mathrm{N}(2 \mathrm{~A})$ & $88.0(4)$ \\
\hline $\mathrm{N}(1)-\mathrm{C}(6)-\mathrm{N}(2 \mathrm{~B})$ & $110.4(6)$ \\
\hline$N(1 A)-C(6 A)-N(2)$ & $110.4(6)$ \\
\hline $\mathrm{N}(1 \mathrm{~B})-\mathrm{C}(6 \mathrm{~B})-\mathrm{N}(2 \mathrm{~A})$ & $110.4(6)$ \\
\hline $\mathrm{N}(1)-\mathrm{Ru}(1)-\mathrm{N}(2)$ & $164.6(4)$ \\
\hline $\mathrm{N}(1 \mathrm{~B})-\mathrm{Ru}(1)-\mathrm{N}(2 \mathrm{~B})$ & 164.6(4) \\
\hline
\end{tabular}

The structure of $\mathrm{Ru}\left({ }^{i} \mathrm{Pr}-\mathrm{Me}-\mathrm{amd}\right)_{3}$ is a distorted trigonal prism with dihedral angles of $97.5,97.5,82.5^{\circ}$. The geometry of the three Ru-N-C-N four membered rings is essentially planar with a mean deviation of 0.0164-0.0165 A, which was also found in the previously reported structures of the transition metal amidinates [17]. The average bite angle is $62.8^{\circ}$, which is quite similar to that of $\mathrm{V}\left({ }^{i} \mathrm{Pr}-\mathrm{Me}-\mathrm{amd}\right)_{3}\left(63.5^{\circ}\right)$ [17]. This is because both metals have similar ionic radii $(\mathrm{Ru} 68$ $\mathrm{pm}, \mathrm{V} 64 \mathrm{pm})$. The mean Ru-N bond distance is $2.08 \AA$, which is similar to what is found in $\mathrm{Ru}(\mathrm{Ph}-\mathrm{Me}-\mathrm{amd})_{3}(2.06$ A) [30] and $\mathrm{Ru}(\mathrm{Tol}-\mathrm{Me}-\mathrm{amd})_{3}(2.07 \AA)$ [31]. Although the ruthenium atom is larger than iron, the mean $\mathrm{Ru}-\mathrm{N}$ bond is a little shorter than the mean $\mathrm{Fe}-\mathrm{N}$ bond found in $\mathrm{Fe}(\mathrm{Ph}-\mathrm{H}-$ famd $)_{3}(2.10 \AA)$, where $\mathrm{Ph}-\mathrm{H}$-famd $=\mathrm{PhNC}(\mathrm{H}) \mathrm{NPh}$ [31]. That may suggest that $\mathrm{Ru}(\mathrm{III})$ is a softer Lewis acid than Fe(III), so back bonding of the amidinate ligand is stronger for $\mathrm{Ru}(\mathrm{III})$ amidinate complexes than for $\mathrm{Fe}(\mathrm{III})$ formamidinate complexes.

The molecular structure of $\mathrm{Ru}\left({ }^{t} \mathrm{Bu}-\mathrm{Me}-\mathrm{amd}\right)_{2}(\mathrm{CO})_{2}$ is shown in Fig. (3).
Some bond distance and angles are listed in Table 2.

Table 2. Selected Bond Distances $(\AA)$ and Bond Angles $\left({ }^{\circ}\right)$ in Compound 6

\begin{tabular}{|c|c|}
\hline $\mathrm{Ru}(1)-\mathrm{N}(1)$ & $2.1171(15)$ \\
\hline $\mathrm{Ru}(1)-\mathrm{N}(2)$ & $2.1481(16)$ \\
\hline $\mathrm{Ru}(1)-\mathrm{N}(3)$ & $2.1479(16)$ \\
\hline $\mathrm{Ru}(1)-\mathrm{N}(4)$ & $2.1166(15)$ \\
\hline $\mathrm{Ru}(1)-\mathrm{C}(5)$ & $1.860(2)$ \\
\hline $\mathrm{Ru}(1)-\mathrm{C}(6)$ & $1.862(2)$ \\
\hline $\mathrm{N}(1)-\mathrm{C}(1)$ & $1.333(2)$ \\
\hline $\mathrm{N}(2)-\mathrm{C}(1)$ & $1.329(2)$ \\
\hline $\mathrm{N}(3)-\mathrm{C}(2)$ & $1.327(2)$ \\
\hline $\mathrm{N}(4)-\mathrm{C}(2)$ & $1.330(2)$ \\
\hline$C(1)-C(4)$ & $1.512(2)$ \\
\hline$C(2)-C(3)$ & $1.513(3)$ \\
\hline $\mathrm{O}(1)-\mathrm{C}(5)$ & $1.150(2)$ \\
\hline $\mathrm{O}(2)-\mathrm{C}(6)$ & $1.149(2)$ \\
\hline $\mathrm{N}(4)-\mathrm{Ru}(1)-\mathrm{N}(3)$ & $61.39(6)$ \\
\hline $\mathrm{N}(1)-\mathrm{Ru}(1)-\mathrm{N}(2)$ & $61.57(6)$ \\
\hline $\mathrm{N}(2)-\mathrm{C}(1)-\mathrm{N}(1)$ & $110.20(15)$ \\
\hline $\mathrm{N}(3)-\mathrm{C}(2)-\mathrm{N}(4)$ & $110.04(16)$ \\
\hline $\mathrm{O}(1)-\mathrm{C}(5)-\mathrm{Ru}(1)$ & $178.82(19)$ \\
\hline $\mathrm{O}(2)-\mathrm{C}(6)-\mathrm{Ru}(1)$ & 178.71(19) \\
\hline
\end{tabular}

The compound crystallizes in the space group $\mathrm{P}(-1)$. The amidinate ligands are coordinated in a dihapto mode with the RuNCN ring having a planar geometry with a mean deviation of $0.0227-0.0230 \AA$. The two ruthenium amidinate planes are essentially orthogonal. The Ru-N1 distance is 0.03 $\AA$ shorter than the Ru-N2 distance, as a consequence of the trans-position of $\mathrm{N} 2$ in relation to the $\mathrm{CO}$ ligand. Compared to the known $\mathrm{Fe}$ (II) cis-carbonyl complex $\mathrm{Fe}\left({ }^{i} \mathrm{Pr}-{ }^{t} \mathrm{Bu}-\right.$ amd $)_{2}(\mathrm{CO})_{2}$ [40], $\mathrm{Ru}\left({ }^{t} \mathrm{Bu}-\mathrm{Me}-\mathrm{amd}\right)_{2}(\mathrm{CO})_{2}$ also has a strongly distorted octahedral geometry. This is due to the very small bite angle of the dihapto-amidinate ligand, i.e. N1-Ru1-N2 is $61.57(6)^{\circ}$ which is similar to $\mathrm{N}-\mathrm{Fe}-\mathrm{N}$ angle of $64.53(5)^{\circ}$ found in $\mathrm{Fe}\left({ }^{i} \mathrm{Pr}-{ }^{t} \mathrm{Bu}-\mathrm{amd}\right)_{2}(\mathrm{CO})_{2}$ [40]. In both complexes, the $\mathrm{C}-\mathrm{M}-\mathrm{C}(\mathrm{M}=\mathrm{Ru}$ or $\mathrm{Fe})$ angle is about $93^{\circ}$; this indicates that the bite angle of the dihapto-amidinate ligand is not sensitive to the metal center.

\section{Properties Related to Vapor Deposition}

There are two very important requirements for ALD precursors: (1) a sufficient thermal stability (> months at the vaporization temperature, $>$ seconds at the deposition temperature); (2) a sufficient volatility (> about 0.1 Torr). We examined the volatility and thermal stability of these three $\mathrm{Ru}$ complexes. $\mathrm{Ru}\left({ }^{i} \mathrm{Pr}-\mathrm{Me}-\mathrm{amd}\right)_{3}$ did not melt under $250{ }^{\circ} \mathrm{C}$. It sublimed at $85{ }^{\circ} \mathrm{C}$ under the pressure of $50 \mathrm{mTorr}$. $\mathrm{Ru}\left({ }^{i} \mathrm{Pr}-\right.$ 
Table 3. Physical Properties of Compounds 4, 5, 6,7

\begin{tabular}{|c|c|c|c|c|}
\hline & Vapor Pressure $\left({ }^{\circ} \mathbf{C} /\right.$ Torr $)$ & M.P. $\left({ }^{\circ} \mathbf{C}\right)$ & Color & blue \\
\hline $\mathbf{4}$ & $85 / 0.05$ & $>250$ & yellow & n/a \\
$\mathbf{5}$ & $50 / 0.045$ & 122 & pale yellow & 44 \\
$\mathbf{6}$ & $130 / 0.055$ & 204 & colorless & $\mathrm{n} / \mathrm{a}$ \\
$\mathbf{7}$ & $50 / 0.07$ & n/a & & \\
\hline
\end{tabular}

Me-amd $)_{2}(\mathrm{CO})_{2}$ melted around $122{ }^{\circ} \mathrm{C}$, which was also confirmed by differential scanning calorimetry (DSC) (data not shown here). It sublimed at $50{ }^{\circ} \mathrm{C}$ under the pressure of 45 mTorr. $\mathrm{Ru}\left({ }^{t} \mathrm{Bu}-\mathrm{Me}-\mathrm{amd}\right)_{2}(\mathrm{CO})_{2}$ melted around $204{ }^{\circ} \mathrm{C}$ and sublimed at $130{ }^{\circ} \mathrm{C}$ under the pressure of 55 mTorr. No decomposition was observed during the sublimation of all three complexes, showing that all three compounds are stable at the sublimation temperatures listed in Table $\mathbf{3}$.

Thermogravimetric analyses (TGA) of all three ruthenium complexes were performed at atmospheric pressure under a flow of nitrogen. Representative curves are given in Fig. (4).

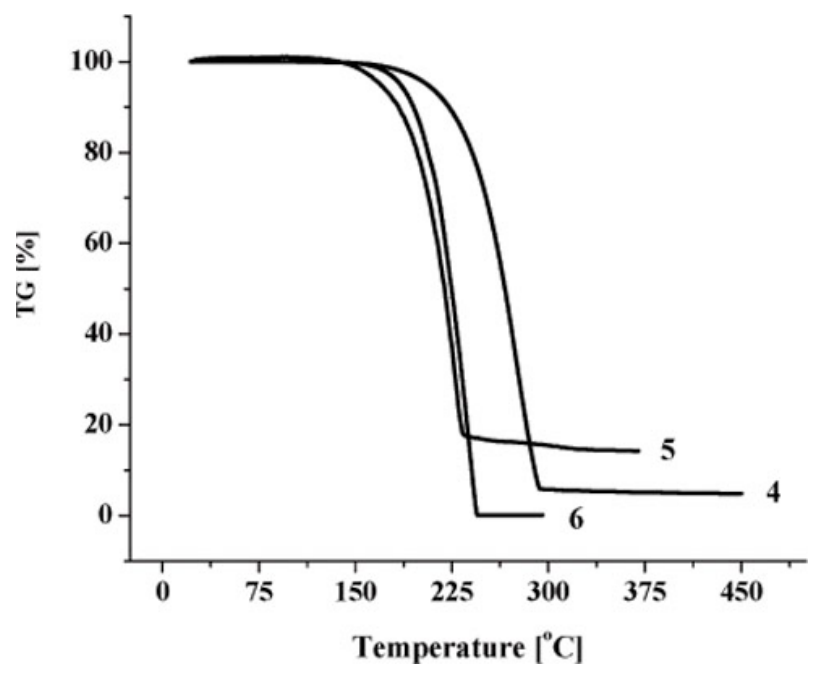

Fig. (4). TGA curves for mass changes of Ru amidinate complexes of 4,5 and 6 measured in a flow of nitrogen at atmospheric pressure.

Vaporization occurs cleanly in one step with different residual masses (4\% left for $\mathrm{Ru}\left({ }^{i} \mathrm{Pr}-\mathrm{Me}-\mathrm{amd}\right)_{3}, 14 \%$ left for $\mathrm{Ru}\left({ }^{i} \mathrm{Pr}-\mathrm{Me}-\mathrm{amd}\right)_{2}(\mathrm{CO})_{2}$, and $0.2 \%$ left for $\mathrm{Ru}\left({ }^{t} \mathrm{Bu}-\mathrm{Me}-\right.$ amd $\left.)_{2}(\mathrm{CO})_{2}\right)$. The high TGA residue left for $\mathrm{Ru}\left({ }^{i} \mathrm{Pr}-\mathrm{Me}-\right.$ amd $)_{2}(\mathrm{CO})_{2}$ had a silvery color, and was presumably metallic ruthenium. This means that about $25 \%$ of the initial $\mathrm{Ru}\left({ }^{i} \mathrm{Pr}-\right.$ Me-amd $)_{2}(\mathrm{CO})_{2}$ decomposed to metallic ruthenium. Preliminary tests of $\mathrm{Ru}\left({ }^{i} \mathrm{Pr}-\mathrm{Me} \text {-amd }\right)_{2}(\mathrm{CO})_{2}$ as a CVD precursor at $200{ }^{\circ} \mathrm{C}$ in the absence of any co-reactant showed deposition of ruthenium films on substrates. This suggests that $\mathrm{Ru}\left({ }^{i} \mathrm{Pr}-\right.$ Me-amd $)_{2}(\mathrm{CO})_{2}$ is a possible precursor for CVD of ruthenium; it is not stable enough for ALD of ruthenium. $\mathrm{Ru}\left({ }^{t} \mathrm{Bu}-\right.$ $\mathrm{Me}-\mathrm{amd})_{2}(\mathrm{CO})_{2}$ showed very little decomposition with only a trace of residue $(0.2 \%)$ in the TGA. It is the most thermally stable of these $\mathrm{Ru}$ compounds. The TGA of $\mathrm{Ru}\left({ }^{i} \mathrm{Pr}-\mathrm{Me}-\right.$ amd $)_{3}$ showed that it vaporized less quickly than the other two compounds.
Thermal decomposition studies in solution at high temperature by ${ }^{1} \mathrm{H}$ NMR were also used to evaluate the thermal stabilities of $\mathrm{Ru}\left({ }^{i} \mathrm{Pr}-\mathrm{Me}-\mathrm{amd}\right)_{3}$ and $\mathrm{Ru}\left({ }^{t} \mathrm{Bu}-\mathrm{Me}-\mathrm{amd}\right)_{2}(\mathrm{CO})_{2}$. The experiments were performed in sealed heavy-wall NMR tubes and the concentration of the solution in deuterated mesitylene was around $3 \mathrm{mM}$. The temperature was $175^{\circ} \mathrm{C}$. The logarithm of the area of an NMR peak (referenced to a solvent peak as an internal standard) vs. time is linear, indicating the decomposition is first order. From the slope, the half-life of the precursors at $175^{\circ} \mathrm{C}$ could be calculated., The half-life is 15 hours for $\mathrm{Ru}\left({ }^{i} \mathrm{Pr}-\mathrm{Me} \text {-amd }\right)_{3}$, and 44 hours for $\mathrm{Ru}\left({ }^{t} \mathrm{Bu}-\mathrm{Me} \text {-amd }\right)_{2}(\mathrm{CO})_{2}$, confirming that the latter compound is more stable.

These results are consistent with the thermal stability observed in bubblers. $\mathrm{Ru}\left({ }^{t} \mathrm{Bu}-\mathrm{Me}-\mathrm{amd}\right)_{2}(\mathrm{CO})_{2}$ is stable in a bubbler at the temperature of $130{ }^{\circ} \mathrm{C}$ for months with very little decomposition, while $\mathrm{Ru}\left({ }^{i} \mathrm{Pr}-\mathrm{Me} \text {-amd }\right)_{3}$ is not stable at $130{ }^{\circ} \mathrm{C}$. After $12 \mathrm{~h}$, the bubbler did not produce any vapor of $\mathrm{Ru}\left({ }^{i} \mathrm{Pr}-\mathrm{Me} \text {-amd }\right)_{3}$ because the decomposed material covered the surface of the remaining solid precursor which led to an extremely slow evaporation rate of the ruthenium complex. Hence $\mathrm{Ru}\left({ }^{t} \mathrm{Bu}-\mathrm{Me}-\mathrm{amd}\right)_{2}(\mathrm{CO})_{2}$ is a better precursor for vapor deposition.

In conclusion, we synthesized and characterized three new monomeric $\mathrm{Ru}$ amidinates. Large-scale preparation of these compounds is possible. Bis(di-tert-butylacetamidinato) ruthenium(II) dicarbonyl 6 was shown to have high thermal stability and sufficient volatility to serve as a vapor-phase precursor for Ru. Successful studies of ALD and CVD Ru thin films using compound $\mathbf{6}$ as a precursor were published separately [41].

\section{EXPERIMENTAL SECTION}

\section{General Considerations}

All reactions were conducted under a nitrogen atmosphere using either standard Schlenk techniques or in a glove box, except the synthesis of mer- $\mathrm{RuCl}_{3}\left(\mathrm{Me}_{2} \mathrm{~S}\right)_{3}$ and $\left[\mathrm{RuCl}_{2}(\mathrm{CO})_{3}\right]_{2}$. Diethyl ether, tetrahydrofuran (THF) and hexanes were dried using an Innovative Technology solvent purification system and stored over $4 \AA$ molecular sieves. Dimethyl sulfoxide (DMSO), methyllithium, silica gel, $N, N^{\prime}$ di-tert-butylcarbodiimide and $N, N^{\prime}$-di-iso-propylcarbodiimide were purchased and used as received from Aldrich. $\mathrm{RuCl}_{3} \cdot 3 \mathrm{H}_{2} \mathrm{O}$ was purchased and used as received from Pressure Chemical. $\left[\mathrm{RuCl}_{2}(\mathrm{CO})_{3}\right]_{2}$, [34] $\left[\mathrm{RuCl}_{2}(\mathrm{CO})_{3}\left(\mathrm{C}_{4} \mathrm{H}_{8} \mathrm{O}\right)\right]$ [42], lithium $N, N^{\prime}$-di-tert-butylacetamidinate and lithium $N, N^{\prime}$-di-iso-propylacetamidinate [17] were synthesized by known literature methods. mer- $\mathrm{RuCl}_{3}\left(\mathrm{Me}_{2} \mathrm{~S}\right)_{3}$ was synthesized from a modified literature method $[35,37,39]$. 


\section{$m e r-\mathrm{RuCl}_{3}\left(\mathrm{Me}_{2} \mathrm{~S}\right)_{3}$}

$\mathrm{RuCl}_{3} \cdot 3 \mathrm{H}_{2} \mathrm{O}(4.00 \mathrm{~g}, 15.2 \mathrm{mmol})$ was dissolved in DMSO $(18 \mathrm{~mL})$. Concentrated $\mathrm{HCl}(80 \mathrm{~mL})$ was added to the obtained syrup and the mixture refluxed at $130{ }^{\circ} \mathrm{C}$ for 1.5 hours. The mixture was then cooled and filtered. A red crystalline compound was then collected. The filtrate was concentrated and DMSO $(12 \mathrm{~mL})$ and conc. $\mathrm{HCl}(60 \mathrm{~mL})$ were added, the mixture was then refluxed for another 30 minutes at $130{ }^{\circ} \mathrm{C}$. The mixture was then cooled and filtered. Another batch of red solid was isolated. The red products were combined and purified by silica gel column chromatography using dichloromethane as the eluant. Yield: $4.6 \mathrm{~g}, 75 \% ;{ }^{1} \mathrm{H}$ NMR (400 MHz, $\left.\mathrm{CDCl}_{3}, 25^{\circ} \mathrm{C}\right): \delta=-10.5$ (s, $6 \mathrm{H}, \mathrm{SMe}_{2}$ ), 21.0 (s, $12 \mathrm{H}, \mathrm{SMe}$ ).

\section{$\operatorname{Ru}\left({ }^{i} \text { Pr-Me-amd }\right)_{3}$}

mer $-\mathrm{RuCl}_{3}\left(\mathrm{Me}_{2} \mathrm{~S}\right)_{3}(5.00 \mathrm{~g}, 12.7 \mathrm{mmol})$ was added to freshly prepared $\mathrm{Li}\left({ }^{i} \mathrm{Pr}-\mathrm{Me}-\mathrm{amd}\right)(5.70 \mathrm{~g}, 38.2 \mathrm{mmol})$ in $\mathrm{Et}_{2} \mathrm{O}(200 \mathrm{ml})$ at $-20{ }^{\circ} \mathrm{C}$. The reaction mixture was allowed to slowly warm up to room temperature and stirred for 24 hours. After removal of solvent under vacuum, the residue was extracted with hexanes and dried in vacuo. The blue residue was loaded in a distillation apparatus and the hydrazine by-product 7 was distilled away; the residue was then purified by sublimation. Yield: $2.10 \mathrm{~g}, 30 \%$. Sublimation: 85 ${ }^{\circ} \mathrm{C}$ at 50 mTorr. ${ }^{1} \mathrm{H}$ NMR for $4\left(400 \mathrm{MHz}, \mathrm{C}_{6} \mathrm{D}_{6}, 25^{\circ} \mathrm{C}\right): \delta$ $=27.931\left(\mathrm{br}, 6 \mathrm{H}, \mathrm{CH}\left(\mathrm{CH}_{3}\right)_{2}\right), 4.595\left(\mathrm{br}, 18 \mathrm{H}, \mathrm{CH}\left(\mathrm{CH}_{3}\right)_{2}\right)$, 5.548 (br, $\left.18 \mathrm{H}, \mathrm{CH}\left(\mathrm{CH}_{3}\right)_{2}\right)$, -18.499 (br, $\left.9 \mathrm{H}, \mathrm{CCH}_{3}\right)$; EI MS: $524.8\left[\mathrm{M}^{+}\right]$for a calculated MW of 524.8; Anal. Calcd. for $\mathrm{C}_{24} \mathrm{H}_{51} \mathrm{~N}_{6} \mathrm{Ru}$ : C 54.93, H 9.80, N 16.01. Found: C 55.04, H 9.65, N 15.92. Side product 7: Yield: from $20 \%$ to $30 \%$. Distillation: $50{ }^{\circ} \mathrm{C}$ at $70 \mathrm{mTorr} ;{ }^{1} \mathrm{H}$ NMR for $7(400 \mathrm{MHz}$, $\mathrm{C}_{6} \mathrm{D}_{6}, 25{ }^{\circ} \mathrm{C}$ ): $\delta=4.436$ (septet, $\mathrm{J}=6.5 \mathrm{~Hz}, 2 \mathrm{H}$, $\left.\mathrm{CH}\left(\mathrm{CH}_{3}\right)_{2}\right), 3.435$ (septet, J = 6.0 Hz, $\left.2 \mathrm{H}, \mathrm{CH}\left(\mathrm{CH}_{3}\right)_{2}\right), 1.558$ $\left(\mathrm{s}, 6 \mathrm{H}, \mathrm{CCH}_{3}\right), 1.238\left(\mathrm{~d}, \mathrm{~J}=6.5 \mathrm{~Hz}, 6 \mathrm{H}, \mathrm{CH}\left(\mathrm{CH}_{3}\right)\left(\mathrm{CH}_{3}\right)\right)$; $1.197\left(\mathrm{~d}, \mathrm{~J}=6.0 \mathrm{~Hz}, 6 \mathrm{H}, \mathrm{CH}\left(\mathrm{CH}_{3}\right)\left(\mathrm{CH}_{3}\right)\right), 1.195(\mathrm{~d}, \mathrm{~J}=6.0$ $\left.\mathrm{Hz}, 6 \mathrm{H}, \mathrm{CH}\left(\mathrm{CH}_{3}\right)\left(\mathrm{CH}_{3}\right)\right), 1.157(\mathrm{~d}, \mathrm{~J}=6.5 \mathrm{~Hz}, 6 \mathrm{H}$, $\left.\mathrm{CH}\left(\mathrm{CH}_{3}\right)\left(\mathrm{CH}_{3}\right)\right) ;{ }^{13} \mathrm{C} \mathrm{NMR}\left(400 \mathrm{MHz}, \mathrm{C}_{6} \mathrm{D}_{6}, 25{ }^{\circ} \mathrm{C}\right): \delta=$ $156.4\left(\mathrm{CCH}_{3}\right), 51.6\left(\mathrm{CH}\left(\mathrm{CH}_{3}\right)_{2}\right), 49.6\left(\mathrm{CH}\left(\mathrm{CH}_{3}\right)_{2}\right), 25.2$ $\left(\mathrm{CH}\left(\mathrm{CH}_{3}\right)\left(\mathrm{CH}_{3}\right)\right), \quad 25.0 \quad\left(\mathrm{CH}\left(\mathrm{CH}_{3}\right)\left(\mathrm{CH}_{3}\right)\right), \quad 20.9$ $\left(\mathrm{CH}\left(\mathrm{CH}_{3}\right)\left(\mathrm{CH}_{3}\right)\right), 20.6\left(\mathrm{CH}\left(\mathrm{CH}_{3}\right)\left(\mathrm{CH}_{3}\right)\right), 12.7\left(\mathrm{CCH}_{3}\right) ; \mathrm{HR}$ ES MS: Cal for $\left[\mathrm{M}+\mathrm{H}^{+}\right]$283.2861, Exp. 283.2857; Anal. Calcd. for $\mathrm{C}_{16} \mathrm{H}_{34} \mathrm{~N}_{4}$ : C 68.03, $\mathrm{H}$ 12.13, N 19.83. Found: $\mathrm{C}$ 67.64, H 12.48, N 19.59.

\section{$\operatorname{Ru}\left({ }^{i} \operatorname{Pr}-\mathrm{Me}-\mathbf{a m d}\right)_{2}(\mathrm{CO})_{2}$}

$\left[\mathrm{RuCl}_{2}(\mathrm{CO})_{3}\right]_{2}(2.00 \mathrm{~g}, 3.90 \mathrm{mmol})$ was dissolved in THF $(100 \mathrm{ml})$, then freshly prepared $\mathrm{Li}\left({ }^{i} \mathrm{Pr}-\mathrm{Me}\right.$-amd $)(2.55 \mathrm{~g}, 17.2$ mmol) was added. The reaction mixture was refluxed overnight. After removal of solvent under vacuum, the solid residue was extracted with hexanes and dried in vacuo. The oily residue was then sublimated twice to afford a pure pale yellow solid. Yield: $1.2 \mathrm{~g}, 40 \%$. Mp: $121-122{ }^{\circ} \mathrm{C}$. Sublimation: $50{ }^{\circ} \mathrm{C}$ under 45 mTorr. ${ }^{1} \mathrm{H}$ NMR $\left(400 \mathrm{MHz}, \mathrm{C}_{6} \mathrm{D}_{6}, 25{ }^{\circ} \mathrm{C}\right)$ : $\delta=3.593$ (septet, $\left.\mathrm{J}=6.3 \mathrm{~Hz}, 4 \mathrm{H}, \mathrm{CH}\left(\mathrm{CH}_{3}\right)_{2}\right), 3.312$ (septet, $\left.\mathrm{J}=6.3 \mathrm{~Hz}, 4 \mathrm{H}, \mathrm{CH}\left(\mathrm{CH}_{3}\right)_{2}\right), 1.350\left(\mathrm{~s}, 6 \mathrm{H}, \mathrm{CCH}_{3}\right), 1.202$ $\left(\mathrm{d}, \mathrm{J}=6.3 \mathrm{~Hz}, 12 \mathrm{H}, \mathrm{CH}\left(\mathrm{CH}_{3}\right)_{2}\right), 1.145(\mathrm{~d}, \mathrm{~J}=6.3 \mathrm{~Hz}, 12 \mathrm{H}$, $\left.\mathrm{CH}\left(\mathrm{CH}_{3}\right)_{2}\right), 1.103$ (d, J = 6.3 Hz, $\left.12 \mathrm{H}, \mathrm{CH}\left(\mathrm{CH}_{3}\right)_{2}\right), 0.974$ (d, $\left.\mathrm{J}=6.3 \mathrm{~Hz}, 12 \mathrm{H}, \mathrm{CH}\left(\mathrm{CH}_{3}\right)_{2}\right) ;{ }^{13} \mathrm{C} \mathrm{NMR}\left(400 \mathrm{MHz}, \mathrm{C}_{6} \mathrm{D}_{6}, 25\right.$ $\left.{ }^{\circ} \mathrm{C}\right): \delta=200.8(\mathrm{CO}), 170.7\left(\mathrm{CCH}_{3}\right), 48.0\left(\mathrm{CH}\left(\mathrm{CH}_{3}\right)_{2}\right), 47.2$ $\left(\mathrm{CH}\left(\mathrm{CH}_{3}\right)_{2}\right), 25.7\left(\mathrm{CH}\left(\mathrm{CH}_{3}\right)\left(\mathrm{CH}_{3}\right)\right), 25.6\left(\mathrm{CH}\left(\mathrm{CH}_{3}\right)\left(\mathrm{CH}_{3}\right)\right)$,
$25.0\left(\mathrm{CH}\left(\mathrm{CH}_{3}\right)\left(\mathrm{CH}_{3}\right)\right), 23.4\left(\mathrm{CH}\left(\mathrm{CH}_{3}\right)\left(\mathrm{CH}_{3}\right)\right), 10.9\left(\mathrm{CCH}_{3}\right)$; IR $(\mathrm{NaCl}): v_{\mathrm{CO}} 2015,1936 \mathrm{~cm}^{-1}$; Anal. Calcd. for $\mathrm{C}_{18} \mathrm{H}_{34} \mathrm{~N}_{4} \mathrm{O}_{2} \mathrm{Ru}$ : C 49.18, H 7.80, N 12.75. Found: $\mathrm{C} 49.55, \mathrm{H}$ $8.00, \mathrm{~N} 12.55$.

\section{$\mathrm{Ru}\left({ }^{t} \mathrm{Bu}-\mathrm{Me}-\mathrm{amd}\right)_{2}(\mathrm{CO})_{2}$}

$\left[\mathrm{RuCl}_{2}(\mathrm{CO})_{3}\left(\mathrm{C}_{4} \mathrm{H}_{8} \mathrm{O}\right)\right](16.5 \mathrm{~g}, 50 \mathrm{mmol})$ was added to freshly prepared $\mathrm{Li}\left({ }^{t} \mathrm{Bu}-\mathrm{Me}\right.$-amd $)(17.8 \mathrm{~g}, 101 \mathrm{mmol})$ in THF $(400 \mathrm{ml})$. The reaction mixture was stirred overnight and then concentrated under vacuum. The residue was extracted with hexanes and filtered through celite. Then the filtrate was concentrated to afford the crude material, which was later sublimed twice to afford a pure pale yellow-green solid. Yield: $13.7 \mathrm{~g}, 55 \%$. Mp: $203-205^{\circ} \mathrm{C}$. Sublimation: $130{ }^{\circ} \mathrm{C}$ at 55 mTorr. ${ }^{1} \mathrm{H}$ NMR $\left(400 \mathrm{MHz}, \mathrm{C}_{6} \mathrm{D}_{6}, 25{ }^{\circ} \mathrm{C}\right): \delta=1.686(\mathrm{~s}$, $\left.6 \mathrm{H}, \mathrm{CCH}_{3}\right), 1.304\left(\mathrm{~s}, 18 \mathrm{H}, \mathrm{C}\left(\mathrm{CH}_{3}\right)_{3}\right), 1.188(\mathrm{~s}, 18 \mathrm{H}$, $\left.\mathrm{C}\left(\mathrm{CH}_{3}\right)_{3}\right)$. IR $(\mathrm{NaCl}): v_{\text {co }} 2017,1935 \mathrm{~cm}^{-1}$; Anal. Calcd. for $\mathrm{C}_{22} \mathrm{H}_{42} \mathrm{~N}_{4} \mathrm{O}_{2} \mathrm{Ru}$ : C 53.31, H 8.54, N 11.30. Found: C 53.73, H $8.23, \mathrm{~N} 11.65$.

\section{X-Ray Structure Determination}

The complexes $\mathrm{Ru}\left({ }^{i} \mathrm{Pr}-\mathrm{Me}-\mathrm{amd}\right)_{3} \mathbf{4}$ and $\mathrm{Ru}\left({ }^{t} \mathrm{Bu}-\mathrm{Me}-\right.$ amd $)_{2}(\mathrm{CO})_{2} \mathbf{6}$, were structurally characterized by X-ray crystallography. Crystals were grown by cooling saturated hexanes solution to $-30{ }^{\circ} \mathrm{C}$ for two weeks. Diffraction data were obtained with a Siemens (Bruker) SMART CCD area detector system using $\omega$ scans of $0.3 \%$ frames, and 30 -sec frames such that 1271 frames were collected for a hemisphere of data. The first 50 frames were re-collected at the end of the data collection to monitor for crystal decay; no significant decay was observed. Cell parameters were determined using SMART software. Data reductions were performed with SAINT software, which corrects for Lorenz polarization and decay. Absorption corrections were applied using SADABS. Space groups were assigned by analysis of symmetry and observed systematic absences determined by the program XPREP and by successful refinement of the structure. The structure was solved by direct methods with SHELXS and subsequently refined against all data by the standard technique of full-matrix least squares on $F^{2}$ (SHELXL-97).

The asymmetric unit contains one-third of the formula weight of $\mathrm{Ru}\left({ }^{i} \mathrm{Pr}-\mathrm{Me}-\mathrm{amd}\right)_{3}$. All non-hydrogen atoms found in $\mathrm{Ru}\left({ }^{i} \mathrm{Pr}-\mathrm{Me}-\mathrm{amd}\right)_{3}$ and $\mathrm{Ru}\left({ }^{t} \mathrm{Bu}-\mathrm{Me}-\mathrm{amd}\right)_{2}(\mathrm{CO})_{2}$ were described anisotropically. In the final stages of refinement, hydrogen atoms were added at idealized positions and refined as riding atoms with a uniform value of $U_{\text {iso }}$. Crystal data and final agreement factors of both compounds are listed in Table 4.

\section{Physical Measurements}

All measurements were performed under anaerobic conditions. ${ }^{1} \mathrm{H}$ - and ${ }^{13} \mathrm{C}$-NMR spectra were recorded on a Varian Mercury400 spectrometer at $25{ }^{\circ} \mathrm{C}$. Elemental analysis were obtained by Desert Analytics Laboratory, Tucson, AZ. TGA and DSC data were obtained with a Netzsch STA 449C or TA Q50 inside a nitrogen glove box. The sample $\mathrm{N}_{2}$ flow rate is $60 \mathrm{~mL} / \mathrm{min}$. Samples $(10-20 \mathrm{mg}$ ) were loaded in open platinum crucibles. The measurements were done with a temperature ramp rate of $10 \mathrm{~K} / \mathrm{min}$. Melting points were performed in sealed capillaries using a Mel-Temp II apparatus. EI and ES mass spectrum were respectively obtained with a 
Jeol AX-505H spectrometer and a Micromass LCT spectrometer.

Table 4. Crystallographic Data ${ }^{a}$ for Compounds 4 and 6

\begin{tabular}{|l|l|l|}
\hline & \multicolumn{1}{|c|}{4} & \multicolumn{1}{|c|}{ 6 } \\
\hline \hline formula & $\mathrm{C}_{24} \mathrm{H}_{51} \mathrm{~N}_{6} \mathrm{Ru}$ & $\mathrm{C}_{22} \mathrm{H}_{42} \mathrm{~N}_{4} \mathrm{O}_{2} \mathrm{Ru}$ \\
formula weight & 524.78 & 495.67 \\
crystal system. & $\mathrm{Rhombohedral}$ & Triclinic \\
space group & $\mathrm{R} 3$ & $\mathrm{P}-1$ \\
$\mathrm{Z}$ & 3 & 2 \\
$a, \AA$ & $16.0870(10)$ & $10.283(2)$ \\
$b, \AA$ & & $10.297(2)$ \\
$c, \AA$ & $9.2962(13)$ & $11.678(2)$ \\
$\alpha$ & & $86.28(3)$ \\
$\beta$ & 1.054 & $86.42(3)$ \\
$\gamma$ & $4.68(12.27)$ & $87.31(3)$ \\
$V, \AA^{3}$ & & $1230.3(4)$ \\
$d_{\text {calc }}, \mathrm{g} / \mathrm{cm}^{3}$ & 1.255 & 1.338 \\
$\mu, \mathrm{mm}^{-1}$ & 0.585 & 0.660 \\
$\mathrm{GOF}\left(F^{2}\right)$ & & 1.080 \\
$R_{1}{ }^{b}\left(w R_{2}{ }^{c}\right), \%$ & & $2.59(6.23)$ \\
\hline
\end{tabular}

${ }^{a}$ Obtained with graphite monochromated Mo $\mathrm{K} \alpha(\lambda=0.71073 \AA)$ radiation. ${ }^{b} R_{1}=\Sigma \| F_{0}|-| F_{\mathrm{c}}|| \Sigma\left|F_{0}\right|{ }^{c} w R_{2}=\left\{\Sigma\left[w\left(F_{0}{ }^{2}-F_{\mathrm{c}}{ }^{2}\right)^{2}\right]\right\} /\left\{\sum\left[w\left(F_{0}{ }^{2}\right)^{2}\right]\right\}^{1 / 2}$.

\section{ACKNOWLEDGMENTS}

We appreciate the TGA analyses provided by Dr. Xinjian Lei of Schumacher, a unit of Air Products. We are also thankful for Dr. Richards Staples' help in crystal solution and Dr. Jean-Sebastien Lehn for reviewing the manuscript. This work was supported in part by the US National Science Foundation.

\section{Supporting Information Available}

Complete X-ray crystallographic files in CIF format for the structure determinations of the compounds $\mathbf{4}$ and $\mathbf{6}$ can be obtained free of charge from the Cambridge Crystallographic Data Center via www.ccdc.cam.ac.uk/datarequest/ cif. Their deposition numbers are CCDC 675116 and CCDC 675117.

\section{REFERENCES}

[1] The International Technology Roadmap for Semiconductor; Semiconductor Industry Association, http://public.itrs.net, 2007.

[2] Ritala, M.; Leskelä, M. In Handbook of Thin Film Materials; Nalwa, H. S., Ed.; Academic Press: New York, 2001.
[3] Durlam, M.; Chen, E. Y.; Tehrani, S. N.; Slaughter, J. M.; Kerszykowski, G.; Kyler, K. W. US Patent 6211090, 2001.

[4] Atomic Layer Epitaxy; Suntola, T.; Simpson, M., Eds.; Blackie and Sons Ltd.: Glasgow, 1990.

[5] Xiong, W.; Gong, H.; Park, C.-M.; Zhang, J.; Lam, A.; Huai, Y. In MMM Conf. Session HP-03, 2001.

[6] Seidel, T.; Londergan, A.; Winkler, J.; Liu, X.; Ramanathan, S. Solid State Tech., 2003, 46, 67.

[7] Goswami, I.; Laxman, R. Seminconductor Int., 2004, 27, 49.

[8] Hwang, C. S. Mater. Sci Eng. B., 1998, 56, 178.

[9] Tapajna, M.; Pisecny, P.; Luptak, R.; Husekova, K.; Froehlich, K. Harmatha, L.; Hooker, J. C.; Roozeboom, F.; Jergel, J. Materials Sci. Semiconductor Proc., 2004, 7, 271

[10] Green, M. L.; Gross, M. E.; Papa, L. E.; Schnoes, K. J.; Brasen, D. J. Electrochem. Soc., 1985, 132, 2677.

[11] Kwon, O.-K.; Kim, J.-H.; Park, H.-S.; Kang, S.-W. J. Electrochem. Soc., 2004, 151, G109.

[12] Kwon, O.-K.; Kwon, S.-H.; Park, H.-S.; Kang, S.-W. Electrochem. Solid State Lett., 2004, 7 C46.

[13] Hur'yeva, T.; Lisker, M.; Burte, E. P. Chem. Vap. Deposition, 2006, 12, 429.

[14] Aaltonen, T.; Ritala, M.; Arstila, K.; Keinonen, J.; Leskelä, M. Chem. Vap. Deposition, 2004, 10, 215.

[15] Lai, Y.-H.; Chen, Y.-L.; Chi, Y.; Liu, C.-S.; Carty, A. J.; Peng, S.M.; Lee, G.-H. J. Mater. Chem., 2003, 13, 1999.

[16] Li, Z.; Barry, S.; Gordon, R. G. Inorg. Chem., 2005, 44, 1728.

[17] Lim, B. S.; Rahtu, A.; Park, J.-S.; Gordon, R. G. Inorg. Chem., 2003, 42, 7951.

[18] Lim, B. S.; Rahtu, A.; Gordon, R. G. Nat. Mater., 2003, 2, 749.

[19] Park, J.-S.; Gordon, R. G. 2005.

[20] Lim, B. S.; Rahtu, A.; deRouffignac, P.; Park, J.-S.; Gordon, R. G. Appl. Phys. Lett., 2004, 84, 3957.

[21] deRouffignac, P.; Gordon, R. G. Chem. Vap. Deposition, 2006, 12, 152.

[22] deRouffignac, P.; Yousef, A. P.; Kim, K. H.; Gordon, R. G. Electrochem. Solid State Lett., 2006, 9, F45.

[23] deRouffignac, P.; Park, J.-S.; Gordon, R. G. Chem. Mater., 2005 17,4808 .

[24] Kim, K. H.; Framer, D. B.; Lehn, J.-S. M.; Rao, P. R.; Gordon, R G. Appl. Phys. Lett., 2006, 89, 133512/1.

[25] Coulter, M.; Li, Z.; Gordon, R. G. 231st ACS National Meeting, 2006, Atlanta, GA.

[26] Kim, H.; Gordon, R. G. 2007.

[27] Bhandari, H.; Gordon, R. G. 2007.

[28] Kim, H.-H.; Gordon, R. G. 2006.

[29] Li, Z.; Gordon, R. G. Chem. Vap. Deposition, 2006, 12, 435.

[30] Hursthouse, M. B.; Mazid, M. A.; Clark, T.; Robinson, S. D. Polyhedron, 1993, 12,563

[31] Cotton, F. A.; Daniels, L. M.; Maloney, D. J.; Murillo, A. Inrog. Chim. Acta, 1996, 242, 31.

[32] Hayashida, T.; Miyazaki, K.; Yamaguchi, Y.; Nagashima, H. J. Organomet. Chem., 2001, 634, 167.

[33] Marsh, R. E. Acta Crystallogr., Sect. B: Struct. Sci., 2004, 60, 252.

[34] Gibson, D. H.; Hsu, W.-L.; Steinmetz, A. L.; Johnson, B. V. J. Organomet. Chem., 1981, 208, 89.

[35] Chatt, J.; Leigh, G. J.; Storace, A. P. J. Chem. Soc.(A), 1971, 1380.

[36] Cho, C. S.; Oh, B. H.; Shim, S. C.; Oh, D. H. J. Heterocyclic Chem., 2000, 37, 1315.

[37] Jaswal, J. S.; Rettig, S. J.; James, B. R. Can. J. Chem., 1990, 68, 1808.

[38] Jenner, G. J. Mol. Catal., 1989, 55, 241.

[39] Yapp, T. T.; Jaswal, J. S.; Rettig, S. J.; James, B. R.; Skov, K. A. Inorg. Chim. Acta, 1990, 177, 199.

[40] Vendemiati, B.; Prini, G.; Meetsma, A.; Hessen, B.; Teuben, J. H.; Traverso, O. Eur. J. Inorg. Chem., 2001, 3, 707.

[41] Li, H.; Framer, D. B.; Gordon, R. G.; Lin, Y.; Vlassak, J. J. Electrochem. Soc., 2007, 154, D642.

[42] Bruce, M. I.; Stone, F. G. A. J. Chem. Soc.(A), 1967, 1238. 